\title{
Dual Education System in SMK Muhammadiyah Wanareja
}

\author{
Teti Kusumaningsih ${ }^{*}$, Budi Santosa ${ }^{2}$ \\ ${ }^{1}$ SMK Muhammadiyah Wanareja, Cilacap, Indonesia \\ ${ }^{2}$ Universitas Ahmad Dahlan, Jl. Pramuka No. 42, Pandeyan, Umbulharjo, Yogyakarta, Indonesia \\ ${ }^{*}$ Corresponding author, e-mail: tetikusumaningsih1971@gmail.com
}

\begin{abstract}
The purpose of this study was to determine the implementation of dual system education at SMK Muhammadiyah Wanareja, a vocational high school (VHS) in Central Java, Indonesia, starting from the preparation stage to the implementation and the obstacles faced and the solutions implemented. The method in this study used a descriptive qualitative technique with data collection, documentation, and observation. The data analysis technique used the interactive techniques of Milles and Hubberman with the stages of data collection, data reduction, data presentation, and conclusion drawing. Test the validity and reliability of the data using the source triangulation technique. Respondents in this study were the vice principal of public relations affairs, teachers, students, and leaders or trainers from the industry. The results of the study show that the dual system education implemented is going well even though there are some obstacles in its implementation. Industrial work practice activities are carried out for the full six months and based on the results of competency tests carried out by the school after the industrial work practice activities. Data is obtained that students have competencies by following the expertise program and the competency grid determined by the school. Both institutions face obstacles in the implementation of dual system education. The obstacles faced by schools are the nonimplementation of learning normative and adaptive subjects planned with online systems, the limited means of learning vocational and workforce practices. The obstacles faced by the industry are with single instructors and the number of participants in industrial work practices and implementation that are different from each school. Solutions implemented by schools related to normative and adaptive learning during the implementation of industrial work practices, schools conduct material enrichment for one month with a block system.
\end{abstract}

Keywords: Dual education system, Industrial work practices, Partnership.

\section{INTRODUCTION}

Vocational High School (VHS) is an intermediate level education that has specialization, namely preparing graduates to be ready to work. The success of vocational education is reflected in the number of graduates absorbed in the workforce in each generation.

Table 1. Data on unemployment of high school and vocational school graduates

\begin{tabular}{clcccccc}
\hline \multirow{2}{*}{ No. } & \multirow{2}{*}{ Level of education } & \multicolumn{2}{c}{2016 (million) } & \multicolumn{2}{c}{2017 (million) } & \multicolumn{2}{c}{2018 (million) } \\
& & Feb & Aug & Feb & Aug & Feb. & Aug \\
\hline 1. & High School & 1.54 & 1.95 & 1.55 & 1.91 & 1.65 & 1.93 \\
2. & Vocational School & 1.34 & 1.52 & 1.38 & 1.62 & 1.42 & 1.73 \\
\hline
\end{tabular}

Source: Statistics Center Bureau (BPS) (2018).

Based on the BPS data, the unemployment rate of VHS graduates is still quite high compared to equivalent high school graduates who are only 0.2 million. This shows a minimal difference because vocational schools aim to prepare workers, but the fact that BPS data shows the opposite is unemployment of VHS graduates is still quite high 
compared to high school graduates who are not specially prepared for work. The SMK Muhammadiyah Wanareja is a new school that operates in the $2017 / 2018$ school year with two expertise programs, namely automotive light vehicle engineering and industrial pharmacy. Looking at the data in Table 1 about the national unemployment rate is learning for SMK Muhammadiyah Wanareja, how far the pattern of vocational education is packaged so that it can function as a labor printer and form graduates who can master competencies, have industrial work experience, shape work attitudes, and mentality. If the education pattern is not packaged and well planned, the graduates produced will become new contributors to unemployment in Indonesia.

Employment issues in Indonesia, among others: (1) the high number of underemployment, (2) workers Indonesia dominated by unskilled workers (3) the increasing number of an unemployed educated workforce (Wuryandani, 2014). Is SMK Muhammadiyah Wanareja able to provide graduates who are ready to work? This is of course, determined by the pattern of the education system implemented whether or not to produce high competitiveness graduates? By following the function of Vocational School as a printer of labor, the pattern of the vocational education system must be able to equip competencies and work experience in accordance with the needs of the workforce. This is consistent with the opinion that the vocational education system must be able to form skills competencies and work skills that are in line with the needs of the workforce (Woessmann, Hanushek \& Zhang, 2011).

Dual system education is the essence of vocational education because of the function of Vocational School as a printer of labor. SMK Muhammadiyah Wanareja as an educational institution must be able to carry out a pattern of work-based education, this can be realized if it has adequate practice facilities both in quality and quantity, educators who are competent in their field and partnership with industry. Based on the results of preresearch observations, it was found that schools have limitations in the workforce and practical learning facilities for the automotive and pharmaceutical industrial vehicle engineering expertise program.

The implementation of dual system education requires the availability of educational facilities and infrastructure both in quality and quantity. The development of science and technology and industrial technology is swift, requiring VHSs to prepare adequate learning equipment so that graduates who will be produced will have skill abilities according to the demands of changes in industrial development (Wayong, 2012). SMK Muhammadiyah Wanareja as a pioneer school in addition to facing the limitations of infrastructure and technology gaps because of the means of practice used to use technology that has been left behind. With the technological gap faced, vocational practice activities use lagging technology so that students are less familiar with the technology that is by following work competency needs. This situation requires schools to make various efforts, for example, by collaborating with industry in collaborative activities on the use of infrastructure in order to provide adequate learning to equip student competencies.

The government launched the term dual system education since 1997 as an effort to improve the vocational education system in Indonesia. According to Basuki, there are several factors that lead to improved education system vocational undertaken by the government have not been successful, namely: Improving the education system has not been able to print prospective industrial workforce and education system VHS has been based on the need industry, thus the partnership with industry being a necessity

Kusumaningsih, T., \& Santosa, B. (2019). Dual education system in SMK Muhammadiyah Wanareja. Journal of Vocational Education Studies, 2(2), 127-136. DOI:

https://doi.org/10.12928/joves.v2i2.1206. 
(Amiruddin, Hadi \& Djuanda, 2016).

Implementation of a dual system of education in terms of practice and the goal is not a new education system, because has been done since the 1970s (Beeby, 1981). I started the dual system education program by the government in 1997. Thus the term dual system education is possible to occur in different perspectives while looking at the essence of vocational education, some others see in terms of the terms used, namely in the era of education minister Wardiman Djojonegoro. Different viewpoints and conditions of infrastructure and diverse workforce are possible to occur in different implementations of the implemented vocational education system. The state of the school and the implementation of different education systems cause the obstacles faced in implementing the education system also differently.

\section{RESEARCH METHOD}

This research is qualitative research, with descriptive analysis method, which means that the data obtained in the field are described according to reality. The subjects of the study consisted of 11 respondents namely the public relations deputy headmaster and deputy head of the industrial relations field, two vocational school subject teachers, one normative and adaptive teacher, two light automotive vehicle engineering expertise programs, one industrial pharmacy skills program student and four industry advisers. This research was conducted starting September 13, 2018 - 4 January 2019.

Method of data collection by interview, observation, and documentation. To find out the validity of the data obtained using data validation techniques, source triangulation, and methods. Data analysis techniques use Milles and Hubberman with stages: (a) collection of data that is collecting as much data about everything related to dual system education implementation activities through interviews, direct observation in the field and thorough documentation in the field, (b) data reduction is summarizing the data obtained in the field then categorized by theme according to the research grid and data that is not needed to be disposed of, (c) display data that compose the relevant research data in order to become an information that can be summarized in the form of a thematic narrative texts.

\section{RESULTS AND DISCUSSION Results}

Dual system education is the essence of the vocational education system because of the function of the vocational school as a provider of labor. Vocational Schools cannot function as labor providers without cooperation with industry. SMK Muhammadiyah Wanareja collaborated with 8 industries in the Cilacap Barat area and implemented cooperation for industrial work practices, cooperation in the use of infrastructure, apprentice teachers, guest teachers, competency training and industry visits. With this collaboration, learning is carried out in two places, namely in schools and industry, especially in the implementation of industrial work practices. Collaboration with industry is carried out so that schools can provide adequate education services even though schools are in a state of limited means of infrastructure and education. With collaboration with industry, practical learning activities and industrial work practices can be carried out well. This is in accordance with the results of the study stating that the collaboration of partnerships in dual system education is a shared responsibility between Vocational Schools and their partner's work institutions (Hanushek, Woessmann, \& Zhang, 2011) and must provide mutual benefits (Afrita, Imron, \& Arifin, 2018) through the use of

Kusumaningsih, T., \& Santosa, B. (2019). Dual education system in SMK Muhammadiyah Wanareja. Journal of Vocational Education Studies, 2(2), 127-136. DOI:

https://doi.org/10.12928/joves.v2i2.1206. 
infrastructure in student practice activities (Machumu, 2018).

Dual system education is a commitment of two institutions, one form of commitment manifested by the sharing of learning material between schools and industry, namely schools provide adaptive normative learning and basic productive practices and advanced vocational material carried out by industry through industrial work practice activities. Based on the results of the study, essential vocational learning cannot be carried out maximally; this causes students to carry out industrial work practices not yet have sufficient competence so that the process of guidance and training carried out by industry requires more extended time. This shows that the role and function of industry greatly determine the implementation of dual system education implemented. This is in accordance with the opinion stating that industry's responsibility for the formation of competencies can reduce the competency gap of graduates (Saputro \& Sudibyo, 2013).

Normative and adaptive learning in the implementation of dual system education is a pure responsibility of the school and must be based on the existing curriculum structure. Based on the results of the study, normative and adaptive learning during the industrial work practice activities did not go well, originally planned through online learning and using modules. However, based on the results of normative and adaptive learning research during industrial work activities, it cannot be implemented, so learning is provided after industrial work practices with a one-month module and enrichment system. This shows that the school still strives to provide good education services even though it is not in accordance with planning.

In order to improve the vocational competence of students, SMK Muhammadiyah Wanareja added material to the curriculum in terms of self-development namely motorcycle competence. The steps taken by the SMK Muhammadiyah Wanareja are a step right in the midst of very tight labor competition so that the graduates produced will have a double competency. In this case, the SMK Muhammadiyah Wanareja in collaboration with PT KMI (Kawasaki Motor Indonesia) through the "Kawasaki goes to school" activity in the form of training activities aimed at increasing the competence of students and teachers. With the existence of motorcycle competency material, graduates of the automotive light engineering program will have dual competencies, namely motorcycle engines, and car engines. For industrial pharmacy expertise programs during industrial work practices, students get additional online marketing competencies for herbal medicine from CV De Nature Indonesia. Even from the third month of the implementation of industrial work practices, students can already earn income from online marketing that is carried out. This is in accordance with the results of research that the curriculum implemented by VHS must be in accordance with the needs of the industrial labor market (Ogbuanya \& Onyenwe, 2015), multi-curriculum (Wibawa, 2017), curriculum material based on an agreement between the two institutions (Surachim, 2016). Curriculum development is a school innovation in the field of learning, and this will have an impact on graduate competencies generated and assessment of schools (Santosa, 2017) and is the expected structural outcome of education in training in companies and education in schools (Gessler, 2017). With multi-curriculum packaging and the use of adequate infrastructure, it will further guarantee the achievement of student competencies to be better prepared to face the demands of the world of work. This is in accordance with the opinion which states that the obstacles to the implementation of dual system education are the limitations of learning facilities and facilities and the technological gap between schools and industries (Louis \& Peel, 2004).

Programs and activities on the implementation of dual system education are a whole system of vocational education, ranging from class 1 to grade 3. PSG starts from new

Kusumaningsih, T., \& Santosa, B. (2019). Dual education system in SMK Muhammadiyah Wanareja. Journal of Vocational Education Studies, 2(2), 127-136. DOI:

https://doi.org/10.12928/joves.v2i2.1206. 
student admissions to work distribution (Surachim, 2016), so that the implementation is not limited to the implementation of industrial work practices (Ministry of Education and Culture, 1997b). Industrial work practices are educational and training activities with the aim that students have direct work experience in the industry and obtain advanced competencies that are not obtained at school. SMK Muhammadiyah Wanareja carries out industrial work practice activities for 6 months starting from 18th August 2018 to 22nd February 2019. Industrial work practices SMK Muhammadiyah Wanareja misspelled held on 5 industries, namely 1 industry to program the pharmaceutical industry expertise and 4 industries to program light vehicle automotive engineering. Based on the results of research on education and training programs carried out by industry I in industrial work practice activities refer to the competency grid given by the school. With the existence of the grid, increasing the competence of students after following industrial work practices is expected to be in accordance with the competency standards set by the school. Industrial work practices are carried out on industry which are quite simple but have large enough customers so that every day there are jobs that can be used as learning material with a case study system.

The industrial work practice plan was carried out for 6 months, but the results of the study found that the automotive light vehicle engineering expertise program could not meet 6 months, this is because 3 industries implemented a day-to-day shift day shift system with other schools, so that the sufficient period of implementing industrial work practices not maximum for 6 months. Based on the results of the student competency test the industrial work practices carried out by the school found that students who carry out industrial work practices for six full months have higher competency values compared to students who carry out industrial work practices with a shift system. This research is in accordance with the results of the study stating that the length of education and training has an influence on the level of mastery of student competencies (Amirudin, 2015), effective and beneficial to students becoming more ready to enter the world and more adaptable to their work (Hanushek, Woessmann, Ludger \& Zhang, 2011), so that the assessment carried out by the school must be work-based (Santosa \& Dwi, 2019).

\section{Discussion}

The implementation of dual system education at the SMK Muhammadiyah Wanareja is carried out in several stages, namely the preparation and implementation stages. During the preparatory phase, several activities were carried out, namely: Memorandum of Understanding with industry, preparation of infrastructure facilities, preparation of workforce, curriculum preparation, preparation of implementing work teams for industrial work practices, debriefing of industrial work practices. In the implementation phase, dual system education is carried out through several activities: new student admission, cooperation in the use of infrastructure, curriculum synchronization, education, and training programs, monitoring, and evaluation. The partnership program in the field of competency training is a feature of vocational education that integrates the process of education and training (Wibawa, 2017). The education and training programs implemented provide the skills needed in specific jobs (Hamalik, 1990), but are still oriented towards the realization of competencies and work experience of students, because different implementations will produce different levels of skills (Wiemann \& Fuchs, 2018).

The characteristics of different students are a challenge for industry to provide the best training. The large number of students in industrial work practices in some industry has an impact on the process of guidance and training that has not been maximized. With

Kusumaningsih, T., \& Santosa, B. (2019). Dual education system in SMK Muhammadiyah Wanareja. Journal of Vocational Education Studies, 2(2), 127-136. DOI:

https://doi.org/10.12928/joves.v2i2.1206. 
the presence of a single instructor in industry, it also had an impact on the lack of guidance and training because the training process using case studies caused participants not to understand coherently, because the cases faced in each car were different. This is in accordance with the results of the study which stated that the barriers to the implementation of dual system education were due to the limitations of finding representative industry and student characteristics (Damayanti, 2018).

Industry's role in dual system education is very useful in becoming a partner in implementing the vocational education system to create vocational graduates who are ready to work. Industry not only provide education and training, however, have a responsibility also to provide an assessment of the results of education and training that have been implemented. The results of the assessment are related to the competency and the work hood of students during industrial work practices. The results of these assessments are outlined in a certificate and given to students who meet the conditions set by industry. This is in accordance with the opinion that in industry education and training provides an assessment to give recognition and appreciation to work experience possessed (Wayong, 2012). This research is also in accordance with the results of the study stating that the role of industry is very effective in the implementation of dual system education and meets the standards of implementation, reaching 80.8\% (Irwandi, 2016), and $76.2 \%$ (Galang, 2015).

The obstacles to the implementation of dual system education faced by both institutions, both school institutions, and industrial institutions, are the lack of understanding of steps in the implementation process (Mahmudi, 2013), students experience difficulties in adjusting learning patterns from formal education in schools to informal work training systems so that adequate infrastructure is needed (Finch, 1999). The results of research in the implementation of dual system education experienced many obstacles theoretically and conceptually (Remington, 2018), thus requiring the involvement of government and professional and industry associations (Müller \& Armin, 2017). This is in line with the opinion which states the importance of dual system education reforms that must be job-centered, competency-based, and focus on output that will be produced (Gessler, 2016).

\section{CONCLUSION}

Based on qualitative data analysis in this study about the implementation of dual system education at SMK Muhammadiyah Wanareja, it can be concluded that dual system education runs well even though there are several obstacles in its implementation. The implementation of the implementation can be seen from the existence of intensive collaboration between schools and industry as partner institutions in industrial work practices and other activities, namely the use of infrastructure, teacher and student competency training and industry visits. The school chooses to collaborate with the simple industry and is in the Cilacap Barat region to facilitate monitoring and can contribute to improving student competence and improving the education service system. Industrial work practices are carried out for a full 6 months and the school chooses the implementation of industrial work practices carried out in industry which is quite simple but guarantees the achievement of competencies in accordance with the student's expertise program. Based on the results of the competency tests carried out by the school after the industrial work practice activities, the data obtained by students has competencies in accordance with the expertise program in accordance with the competency grid determined by the school.

Schools and industry face obstacles in the implementation of dual system education.

Kusumaningsih, T., \& Santosa, B. (2019). Dual education system in SMK Muhammadiyah Wanareja. Journal of Vocational Education Studies, 2(2), 127-136. DOI:

https://doi.org/10.12928/joves.v2i2.1206. 
The obstacles faced by schools are the lack of learning of normative and adaptive subjects planned with the system and online, the limitations of the means of learning vocational practices and workforce. Online learning cannot be implemented because some students do not have an Android cellphone and data package, as well as low internet networks in the area. The limitations of facilities and infrastructure have caused schools to be unable to provide necessary vocational skills before students carry out industrial work practices. This of course makes industry's responsibility even greater for equipping skills to students participating in industrial work practices. The obstacle faced by industry is that with a single instructor and the number of participants in the industrial work practices and implementation that are different from each school, the process of guidance and training is repeated so that it is not sufficient.

The solutions implemented by the school are related to adaptive normative learning during the implementation of industrial work practices, the school conducts material enrichment for 1 month with a block system for students to take part in midterm assessments activities and final semester assessment. With the limited means of learning practices and schoolwork, the solution is to collaborate with the use of infrastructure, send teachers to take part in training and bring in guest teachers from the industry. Thus the final conclusion in this study is that collaboration with industry becomes the key to the implementation of dual system education and in industrial work practices it does not have to be in large but industry that can provide technical competence and work experience.

The findings of this study have implications: (a) the need to increase cooperation with industry that is strong, (b) need to provide basic competency training, (c) need to improve and enhance the competence of practical teachers, (d) need for additional learning facilities, (e) improvement of normative and adaptive learning strategies.

This study sought a solution to the barriers to the implementation of industrial work practices at the Muhammadiyah Wanareja Vocational School. Obstacles to online theory learning that are not implemented when students practice industrial work, the solution, is that students follow learning with the block model. Barriers to teachers whose competency qualifications are lacking, the answer, teachers take training in the industry. While it is an obstacle to the lack of practice facilities in schools, the solution, the industry helps schools provide practical facilities for students.

\section{ACKNOWLEDGEMENT}

I express my gratitude to the supervisor and to the Regional Leaders of Muhammadiyah and the Dikdasmen Council who have allowed this research, the teachers and employees of the SMK Muhammadiyah Wanareja who have assisted the research process so that it runs smoothly.

\section{REFERENCES}

Afrita, I., Imron, A., \& Arifin, I. (2018). Manajemen Hubungan Sekolah dengan Dunia Usaha dan Industri dalam Meningkatkan Prestasi Belajar Peserta Didik Sekolah Menengah Vokasional. Jurnal Administrasi dan Manajemen Pendidikan, 1(3), 313-319.

Amiruddin, A., Kustono, D., Hadi, S., \& Djuanda, D. (2016). Analisis implementasi pendidikan sistem ganda pada SMK masa studi 3 tahun dan 4 tahun. Jurnal Teknologi, Kejuruan, dan Pengajarannya Teknologi dan Kejuruan: Jurnal teknologi, Kejuruan dan Pengajarannya, 39(1), 87-98.

BPS. (2018). Tingkat pengangguran terbuka. Retrieved from https://www.bps.go.id/tingkat-pengangguran-terbuka.

Kusumaningsih, T., \& Santosa, B. (2019). Dual education system in SMK Muhammadiyah Wanareja. Journal of Vocational Education Studies, 2(2), 127-136. DOI:

https://doi.org/10.12928/joves.v2i2.1206. 
Beeby, C. E. (1981). Pendidikan di Indonesia penilaian dan pedoman perencanaan. Jakarta: LP3ES.

Damayanti, R. (2018). Komparasi kompetensi peserta didik pendidikan sistem ganda SMK program 4 tahun di SMKN 5 Surabaya dengan SMK Program 3 tahun di SMKN 2 Surabaya. Inspirasii Manajemen Pendidikan, 6(1), 1-6.

Finch, C. R., \& Crunkilton, J. R. (1999). Curriculum development in vocational and technical education. planning, content, and implementation. Needham Heights: Allyn and Bacon.

Galang, W. \& F, Abdullah Taman. (2016). Evaluasi penerapan sistem manajemen mutu berstandar ISO 9001-2008 terhadap hasil pelaksanaan program pendidikan sistem ganda. Kajian Pendidikan Akuntansi Indonesia, 5(7), 1-16.

Gessler, M. (2017). Areas of learning: the shift towards work and competence orientation within the school-based vocational education in the German Dual Apprenticeship System. In Competence-based Vocational and Professional Education (pp. 695-717). Springer, Cham.

Hamalik, O. (1990). Pendidikan Tenaga Kerja Nasional: Kejuruan, Kewirausahaan dan Manajemen. Bandung: PT Citra Aditya Abadi.

Hanushek, E. A., Woessmann, L., \& Zhang, L. (2011). General Education, Vocational Education, and Labor-Market Outcomes over the Life-Cycle. NBER Working Paper No. 17504. National Bureau of Economic Research.

Irwandi, A., \& Sukirno, S. (2016). Efektivitas program pendidikan sistem ganda pada dunia usaha dan dunia industri bidang keahlian akuntansi. Kajian Pendidikan Akuntansi Indonesia, 5(5), 1-11.

Louis, L. W., \& Peel, H. A. (2004). Collaborative Model for School Reform Thought a Rural School/University Partnership. Education Journal, 126(2), 346-352.

Machumu, P. (2018). Efektivitas Program Sistem Pendidikan Ganda Di SMK Praktik Industri Siswa (Prakerin) Di Universitas. Studi Kasus Universitas Negeri Malang. Dissertation, Malang: Program Pascasarjana Universitas Malang.

Mahmudi, M. (2013). Pelaksanaan Pendidikan Sistem Ganda Bersertifikat ISO di SMK Negeri 1 Malang. Jurnal Kebijakan dan Pengembangan Pendidikan, 1(2), 101-111.

Ogbuanya, T., \& Arimonu, M. O. (2015). Regenerating Technical and Vocational Education for Sustainable Youth Empowerment in Nigeria. Journal of Education and Practice, 6(36), 61-64.

Remington, T. F. (2018). Public-private partnerships in TVET: adapting the dual system in the United States. Journal of Vocational Education \& Training, 70(4), 497-523.

Santosa, B, \& Dwi, S. (2019). Work-based assessment at vocational high school in Indonesia. International Journal, 8(1), 89-97. DOI: https://doi.org/10.5861/ijrse.2018.3011.

Santosa, B. (2017). Integrated competency based assessment in vocational secondary high school in Yogyakarta. Regionalization and Harmonization in TVET: Proceedings of the 4th UPI International Conference on Technical and Vocational Education and Training (TVET 2016). Bandung: Universitas Pendidikan Indonesia.

Saputro, H., Pr, B., \& Sudibyo, C. (2013). Peta kompetensi profesi operator mesin produksi dan gap kompetensi antara lulusan SMK jurusan teknik pemesinan dengan tuntutan dunia kerja. Jurnal Ilmiah Pendidikan Teknik dan Kejuruan, 6, 38-46.

Kusumaningsih, T., \& Santosa, B. (2019). Dual education system in SMK Muhammadiyah Wanareja. Journal of Vocational Education Studies, 2(2), 127-136. DOI:

https://doi.org/10.12928/joves.v2i2.1206. 
Surachim, A. (2016). Efektifitas pembelajaran pola pendidikan sistem ganda. Bandung: Alfabeta.

Undang-Undang Sisdiknas, (2003). Sistem Ganda (PSG) pada Sekolah Kejuruan dengan Kebutuhan Dunia Kerja. Prosiding APTEKINDO, 6(1), 379-384.

Wibawa, B. (2017). Manajemen pendidikan teknologi dan kejuruan. Jakarta: Bumi Aksara.

Wiemann, J., \& Fuchs, M. (2018). The export of Germany's "secret of success" dual technical VET: MNCs and multiscalar stakeholders changing the skill formation system in Mexico. Cambridge Journal of Regions, Economy and Society, 11(2), 373386.

Woessmann, L., Hanushek, A.r; E., \& Zhang, L. (2011). General education, vocational education, and labor-market outcomes over the life-cycle. Retrieved from http://nbnresolving.de/urn:nbn:de:101:1-201111213047.

Wuryandani, D. (2014). Peluang dan tantangan sumber daya manusia Indonesia menyongsong era masyarakat ekonomi ASEAN. Info Singkat Ekonomi dan Kebijakan Publik, 6(17), 13-16. 
Kusumaningsih, T., \& Santosa, B. (2019). Dual education system in SMK Muhammadiyah Wanareja. Journal of Vocational Education Studies, 2(2), 127-136. DOI:

https://doi.org/10.12928/joves.v2i2.1206. 